\title{
THE CHALLENGE OF GOING DIGITAL
}

\author{
Marijana VIDAS-BUBANJA ${ }^{1}$, Iva BUBANJA ${ }^{2}$ \\ ${ }^{1}$ Belgrade Business School, 11000 Belgrade, Kraljice Marije 73, Republic of Serbia \\ E-mail: marijana.bubanja@bbs.edu.rs \\ ${ }^{2}$ Belgrade Business School, 11000 Belgrade, Kraljice Marije 73, Republic of Serbia
}

Paper received: 01.11.2017.; Paper accepted: 26.11.2017.

\begin{abstract}
Modern business environment changes under the influence of the second wave of disruptive digital technologies such as mobile applications, social networks, cloud computing, big data analytics and Internet of things. The specificity of these digital innovations defined as The Fourth industrial revolution is that they bring about changes in the complete industry sectors becoming in this way a key condition for further competitive business operations in the global market. This paper analyses the contribution of new digital technologies to economic growth of national economies and higher productivity and competitiveness of companies. In order to maintain competitiveness level, modern enterprises have to start the process of digital transformation that requires new organization models, redesigned business processes and new ways of communication with partners and customers. According to some authors this is the biggest transformation in business the world has seen in over a century. The untapped potential here really is enormous and it represents big challenge for all industries and national economies. EU experiences in the development of digital entrepreneurship are analyzed, as well as challenges of digital change in domestic companies.
\end{abstract}

Keywords: Information-communication technology, Growth, Productivity, Innovation, Competitiveness.

\section{INTRODUCTION}

The fourth industrial revolution driven by the uptake of advanced digital technologies, innovative business models and processes influences the way industries and enterprises of all sizes reinvent their businesses, offering new value propositions, smart products and smart services, and reaching out to new clients. These technologies and new disruptive business models are evolving rapidly and redefining the rules of the global economy, creating new markets and unprecedented business opportunities, (European Commission, 2017). The key challenge for Serbia is to ensure that traditional industry and services companies can fully capture the opportunity and value of digitalization. Serbian businesses are lagging behind in the uptake of advanced digital technologies, with companies slow to adopt new digital technologies. This is a challenge for business and necessitates action at local and national level.

\section{DIGITAL COMPANY}

Digital companies are characterized by a high intensity of utilization of novel digital technologies to improve business operations, invent new business models, sharpen business intelligence, and engage with customers and stakeholders. These technologies hold potential for the creation of new business value to companies, thanks to market opportunities, higher revenue streams, "faster time to market", enhanced service provision, increased productivity and competitiveness (European Commission, 2015). This is the reason why digital companies are recognized by policymakers as central to economies through their contribution to wealth creation, income generation, output and employment.

Digital companies are applying technology in order to enable new types of products and processes rather than simply enhancing existing processes and modes of interaction. Because of this, digital 
strategy of a company depends on the use of digital assets in new ways. Digital transformation cannot be separated from technology, but it also requires a culture that encourages the enterprise to change in real time with a business landscape, which changes constantly. This is not easy, and often involves a good deal of catching up to digital leaders. (Kerschberg, 2017)

\section{NEW WAVE OF DIGITAL TECHNOLOGIES}

According to European Digital Transformation Scoreboard (EDTS) 2017 there are seven important digital technologies for doing successful business today and they are: mobile services, social media and cloud technologies, Internet of things, cyber security solutions, robotic and automated machinery, big data and data analytics (Figure 1). These specific technologies were chosen because they represent the current most prominent new digital technologies, enabling the rapid transformation of industries and the way businesses operate in the digital paradigm. (European Commission, 2017)

\section{Technological focus}

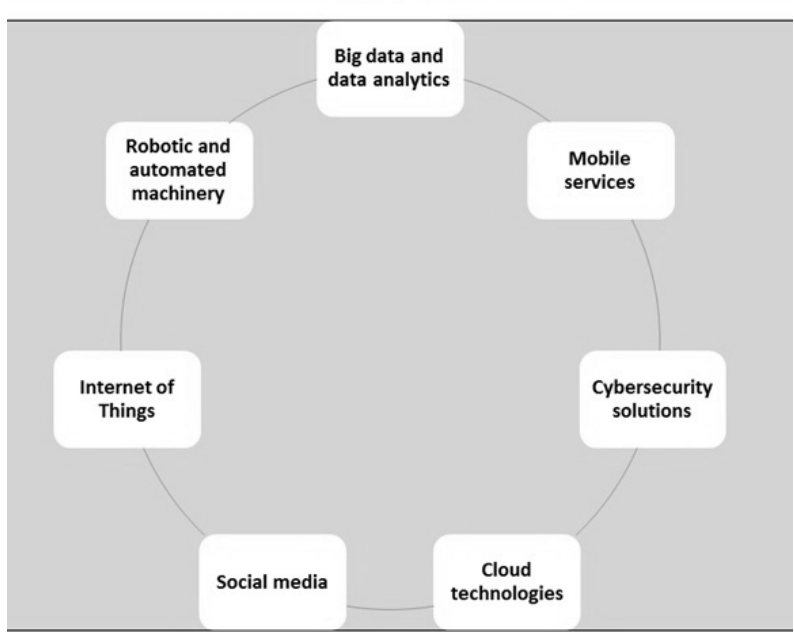

Figure 1: Seven important digital technologies Source: EC, 2017, p. 9

The adoption of at least two of the seven key digital technologies (Table 1) requires particular skill sets and the existence of a specific digital transformation strategy to reap their full benefits. Large firms are more likely than SMEs to have employees with these required skills, which explain the higher rate of large firms adopting key technologies. In addition, SMEs often lack awareness of the positive outcomes for their businesses that could arise from setting up an integrated digital transformation strategy. (European Commission, 2017)

According to McKinsey Global Institute new digital technologies should be observed both in terms of potential economic impact and capacity to disrupt, because these effects go hand-in-hand and because both are of critical importance to leaders (Manyika et al., 2013). As the early 20th-century economist Joseph Schumpeter (Schumpeter, 1950) observed, the most significant advances in economies are often accompanied by a process of "creative destruction", which shifts profit pools, rearranges industry structures, and replaces incumbent businesses. This process is often driven by technological innovation in the hands of entrepreneurs. For this reasons following characteristics of new digital technologies are positioned high on the importance level list (Manyika et al., 2013):

- The technology is rapidly advancing or experiencing breakthroughs. Disruptive technologies typically demonstrate a rapid rate of change in capabilities in terms of price/performance relative to substitutes and alternative approaches, or they experience breakthroughs that drive accelerated rates of change or discontinuous capability improvements.

- The potential scope of impact is broad. To be economically disruptive, a technology must have broad reach - touching companies and industries and affecting (or giving rise to) a wide range of machines, products, or services. The mobile Internet, for example, could affect how five billion people go about their lives, giving them tools to become potential innovators or entrepreneurs - making the mobile Internet one of our most impactful technologies. And the Internet of Things technology could connect and embed intelligence in billions of objects and devices all around the world, affecting the health, safety, and productivity of billions of people.

- Significant economic value could be affected. An economically disruptive technology must have the potential to create massive economic impact. The value at stake must be large in terms of profit pools that might be disrupted, additions to GDP that might result, and capital investments that might be rendered obsolete. Advanced robotics, for example, has the potential to affect $\$ 6.3$ trillion in labour costs globally. Cloud technology has the potential to 
improve productivity across $\$ 3$ trillion in global enterprise IT spending, as well as enabling the creation of new online products and services for billions of consumers and millions of businesses alike.

\section{Table 1: The second wave of digital technologies}

Mobility and mobile apps: Technologies that enable voice and data connections between people, and increasingly between objects, while on the move. Businesses are adopting mobile services with the purpose of enhancing competitiveness, engaging with customers, and enhancing services. In the digital economy, services can be provided and improved through the proper use of mobile services technologies which help reach a customer base and can deliver enhanced services. Furthermore, businesses adopting this technology also declare the improvement of marketing and advertising strategies and the analysis of information on products, services and employees as additional main purposes for adopting this technology. Monitoring the use of mobile services is a prime indicator of how digital technologies influence the way in which businesses work.

Social media: Enterprise social media describes companies' use of social media tools for business purpose. These tools may include social networks (e.g. Facebook, LinkedIn, etc.), micro blogging (e.g. Twitter), blogs, internal wikis and/or other enterprise collaborative software. Social media has a wide-ranging impact on digital entrepreneurs, such as providing a better insight into customer behavior and improved office productivity with internal networks. Recent trends include social media going company-wide beyond marketing and community and allowing for real-time communication and information sharing.

Cloud: Cloud computing is a model for enabling convenient, on-demand network access to a shared pool of configurable computing resources (e.g. networks, servers, storage, software, applications and services) that can be rapidly provisioned and released with minimal management effort or service provider interaction. Important business data forms and other documents can now be accessed from virtually anywhere. Cloud computing is making it easier to do business, creating a more dynamic entrepreneurial culture.

Big data analytics: It refers to the process of collecting, organizing and analyzing large sets of data ("big data") from a variety of different sources to discover and derive value from patterns and other useful information. Companies are beginning to utilize big data and data analytics to gain business insights. As analytical technologies mature, they will leverage what computers do best, while freeing decision-makers from complex data analysis to deliver "intelligence in the moment". This "information advantage" will speed the transition from data to insight and drive better business decisions and actions, thus generating superior business results.

The Internet of Things (IoT): IoT describes the network of physical objects that feature an IP address for Internet connectivity, and the communication that occurs between these objects and other Internet-enabled devices and systems. From monitoring the flow of products through a factory to measuring the moisture in a field of crops to tracking the flow of water through utility pipes, the Internet of Things allows businesses and public-sector organizations to manage assets, optimize performance, and create new business models.

Cyber security solutions: Cyber security has never been more essential, as companies have more digital assets than ever before and these assets are worth more than they used to. The increasingly used hybrid cloud architecture requires a more sophisticated approach to cyber security. The pervasive use of mobile devices by employees means that corporate IT now has to manage the security of many more devices.

Robotic and automated machinery: Robotics can disrupt business models and shift the labour/capital mix while managing societal expectations. End-user industries are rapidly adopting robots for industrial purposes to improve the quality of products and reduce manufacturing costs.

Source: European Commission, 2015, p. 19 and European Commission, 2017, p. 7

- Economic impact is potentially disruptive. Technologies that matter have the potential to dramatically change the status quo. They can transform how people live and work, create new opportunities or shift surplus for businesses, and drive growth or change comparative advantage for nations.

There are two waves of company digitalization. The first wave is based on early digital innovation technologies and the second wave on the new digital technologies started after 2010 (Figure 2). According to European experiences, companies find easier to implement mainstream technologies that correspond to more "basic technologies" (i.e. broadband access and greater bandwidth, IT infrastructure, digital tools for accounting, CRM applications, etc.). These technologies can also be referred to as technologies from the "first digital wave". Implementation process of novel digital technologies (the second digital wave) is more challenging, resulting in the gap between those companies under the first digitalization wave and much lower percent of those under the second digitalization wave. (European Commission, 2017) 
According to survey results performed under the EDTS 2017 the top two technologies adopted by European companies are mobile services and social media $(31 \%$ of the business population declaring positive outcomes), followed by cloud technology and robotic and automated machinery (29 and $27 \%$ ). This observation confirms previous analyses reflecting the importance given by businesses to social media and mobile technologies, and stresses the assumption that in the current digital paradigm, businesses do prioritize rapidly deployable and scalable technologies as the first step to ensure their digital transformation. Once a critical mass of products, services and customers is reached, attention will have to turn to analysis and protection of large volumes of data. (European Commission, 2017)

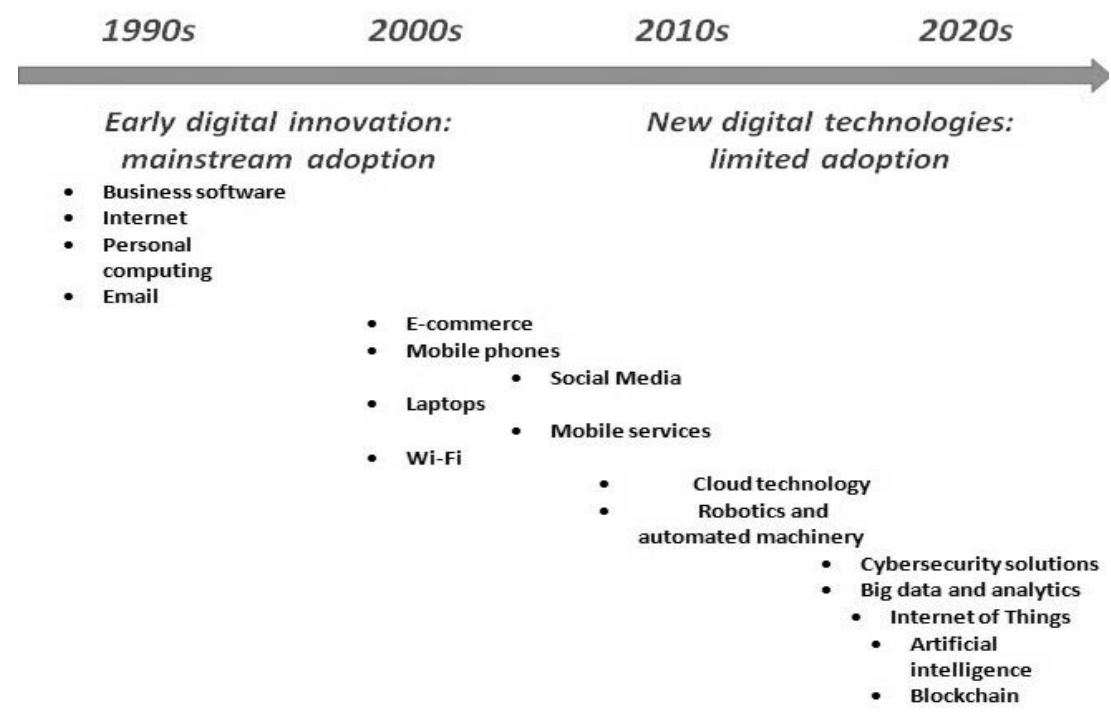

Figure 2: Waves of digitalization

Source: European Commission, 2017, p. 10

\section{GOING DIGITAL}

To perform the process of going digital for a company means much more than just buying the latest IT system. Companies do need assets like computers, servers, networks, and software, but those purchases are just the start. Digital leaders stand out from their competitors in two ways: how they put digital to work, especially in engaging with clients and suppliers, and how intensively their employees use digital tools in every aspect of their daily activities. In order to fully understand the process of going digital, managers of companies should be aware of three broad categories, (Gandhi et al., 2016):

1. First, digital assets. To benchmark them, companies measure how much they invest in hardware, software, data, and IT services: What is also relevant is the extent to which companies are digitizing their physical assets — that is, whether they have smart buildings, connected vehicle fleets, and big data or IoT systems that get maximum performance out of equipment, systems, and supply chains;

2. Second, digital usage. It measures the extent to which companies engage digitally with customers and suppliers. Companies that are leaders in digitalization make more extensive use of digital payments, digital marketing, and design-led product development. They are more likely to use software to manage their backoffice operations and customer relationships. They take advantage of e-commerce platforms and may even operate their own. Their underlying business processes make use of social technologies to interact with customers and partners. This digital usage supports related innovations that are likely to have profound implications on business models and economics across the value chain of companies in the coming years.

3. Third, digitally empowered workforce. It means the degree to which companies put digital tools in the hands of their employees to ramp up productivity. The introduction of various digital labour metrics is not simple and it encompasses for example the share of tasks involving digital tools and the number of new digital occupations in the company. Technology still hasn't penetrated much of the everyday work performed by many world workers, which means that most businesses are missing 
opportunities for greater efficiency and better customer experience. Many still need to break out of their old habit of housing "digital talent" in a separate department. Companies increasingly need each employee to bring greater digital skills to bear on every activity. That's the only way to unleash innovation and capture efficiencies at an institutional level. In some cases, new hires may be necessary, but investing in ongoing employee capability building and cultural change could pay real dividends.

\section{WHAT IS CHANGED IN DIGITALIZATION PROCESS}

By going digital companies will be able to face all the challenges of global digital business environment and new requirements connected with the necessary change of their products, business processes, business models, required skills and knowledge, (Blanchet et al., 2014). Through the digitalization process companies combine innovative operational model with cheaper more customized product, faster service and improved customer experiences. The main benefit of digitalistaion process for companies is higher interactivity with customers and rising capability of meeting all customer's expectations, what is definitely going to be the critical element of competitiveness in the future period. In this respect main characteristics of product, business processes, business model, competition, skills and globalization under the digitalization process will be analised.

1. Product. Digitalization brings more freedom and flexibility into the production process. As a result, product is personalized, locally produced through mass customization. In digital companies it will become possible to create personalized products tailored to segment-by-one customer needs at relatively low marginal cost. (VidasBubanja \& Bubanja, 2017).

2. Business processes. Companies support network manufacturing concept and cluster dynamics in the digitally connected world. Businesses will operate in dispersed digital locations in accordance with available skills raising the complexity of production and supply networks significantly. Owing to the blurring frontiers between the information and physical worlds entry barriers for smaller or more specialized companies will lower. The phenomenon called "industrial democracy" will be enabled resulting in changed distribution of power between multinationals and SMEs or much focused market players. This type of approach could lead to "mobile manufacturing units": small and autonomous manufacturing cells that could be shipped in some countries to locally develop production for the local market without building a full plant. Such a change in business processes could modify the approach of industrial foreign direct investment with regards to emerging markets and localization needs. (Blanchet et al., 2014)

3. Business model. Digitalization is based on the fragmentation of the value chain. Business models of complex and intertwined manufacturing network change the roles of designers, physical product suppliers and the interfaces with the customer. As business leaders rethink and restructure their value chains new challenges in regard to cost and profit ownership arise, and small companies enter the market owing to lower barriers to entry. New business models could also be created if the "long tail" philosophy that was brought up by the Internet can be extrapolated to the Internet of things, (Blanchet et al., 2014).

4. The competition. In the new digital business environment of converging frontiers traditional industry boundaries are becoming blurred, as are the boundaries between industrial and nonindustrial applications. Under this competition rules the focus will be on industrial working methods, including the reproducibility not only of identical products but also of services. Services can be mass-produced too. High-quality digital (outsourced) services and a fail-safe, comprehensive digital infrastructure are becoming the fundamental prerequisites for successful digitalization process. (Vidas-Bubanja \& Bubanja, 2017)

New competition environment is characterized by even closer cooperation between IT/telecommunications firms and traditional manufacturing companies. In fact, IT firms are becoming the new industry leaders. The most recent examples: Facebook is acquiring a stake in the drones business and Internet giant Google is entering the biotech sector and researching new methods of combating age-related diseases. Today, physical machine and tooling suppliers harvest the biggest margins with their industry clients. But in a cyberphysical system world, these suppliers will lose importance. Instead, suppliers of sensors, IT and 
software might take their place in Industry 4.0, while machine and tooling companies shift down to tier 2. (Blanchet et al., 2014)

5. Skills. The digital business concept need both enhanced social and technical skills that will enable design thinking instead of production thinking. The dominant technologies of digital world will be IT, electronics and robotics. But it will also embrace other knowledge areas such as biotech and nanotech. Corporate cultures with continuous training and development in the workplace and lifelong learning are becoming a core competency. A lot of collaborative and crosscultural competencies will be required to be able to work in network environments sustainably. The technical competency profile will be interdisciplinary rather than specialized. Analytics specialists, engineers and programmers will have to be able to think across business models, production processes, machine technology and data-related procedures. Education and training is becoming an integral part of every job. The following axioms in the field of human resources management in the 21 st century are considered, (Lekić et al., 2014): continuing education is essential and mandatory for employees and employers; information technology affects all jobs - no one is safe, nor can its impact be ignored; change is normative; work is highly interdependent in terms of business, in terms of communication and transport in different areas of activity; there is no standard way on the career ladder and progress.

6. Globalization. Organizations will be set up in a much more decentralized and flexible way. Because of this in the new industrial revolution the organization of the future will concentrate on selected hotspots, rather than a comprehensive global presence. There will be open production sites ("makerspaces") and clusters. Firms will not necessarily have to sustain huge production sites to operate cost-efficiently. Sometimes it will be cheaper to transfer data and produce locally on a small scale. (Blanchet et al., 2014)

\section{AGILITY AS A RESPONS TO DIGITALIZATION CHALLENGE}

Digital disruption is an issue for firms in all sectors and industries. To counter these potentially existential threats companies need to change, but not just change, they need to transform. Digital business transformation is a journey to adopt and deploy digital technologies and business models to improve performance quantifiably. Many companies will benefit enormously from digitization. Others will not. The real question then is which organizations will succeed? (Wade \& Tarling, 2016)

To win in the process of digital transformation companies must be dynamic enough to understand and respond to the risks disruptors pose. As margins from core models decline, the percentage of revenue from new businesses needs to increase. This puts pressure on companies to improve the 'hit rate' of marketable innovation and the good answer to this challenge is development of 'digital business agility.' Companies that possess digital business agility respond quickly and effectively to emerging threats to their business, and seize new market opportunities before their rivals even notice them, (Marković, 2016).

According to some authors (Wade \& Tarling, 2016) digital business agility has three main pillars: hyperawareness, informed decisionmaking, and fast execution. These pillars are not technologies, but rather technology-enabled capabilities.

1) Hyperawareness is a company's ability to detect and monitor changes in its business environment. By 'business environment', we mean both the internal and external factors that impact the company's opportunities and risks. Hyperaware companies are less likely to be taken by surprise and are hard to disrupt because they can sense their vulnerabilities and adjust models and processes accordingly. For example, hyperaware companies understand when their customers are dissatisfied and why. Likewise, when a company is hyperaware of its competitive landscape, it understands the strength and weaknesses of traditional rivals, and the potential impact of new lines of business or acquisitions. They also anticipate which non-traditional competitors could threaten their market position, and the models they could use to disrupt, (Wade \& Tarling, 2016).

2) Informed decision-making is a company's ability to make the best decision possible in a given situation. To do this, data collected as part of company hyperawareness processes must be analyzed, scaled, packaged, and distributed throughout the organization. To excel in informed decision-making, companies 
must develop mature data analytics capabilities that augment human judgement (Marković, 2016). However, many companies fail despite having the information they need to make the right moves. Often, this is because assumptions held by top management were not tested or questioned. Decisions based purely upon "gut feeling" or past experience have little chance of success. Instead, companies must make decisions based on insights gleaned from data analysis, and ensure that experts from within and outside of the organization have access to these insights. Diversity of perspective is a major contributor to informed decision-making but is only one element of a larger imperative of corporate inclusion, , (Wade \& Tarling, 2016).

3) Fast execution is a company's ability to carry out its plans quickly and effectively. Unfortunately, it is a rare capability, especially in large companies where execution is slowed by organizational complexity, cultural inertia, turf wars and a reluctance to invest in resources needed to get the job done.

\section{DIGITAL TRANSFORMATION OF EUROPEAN INDUSTRY}

The European Commission recognizes the key role that digital technologies can play in improving the business landscape in Europe and has taken action to support digital transformation, placing this issue at the core of many key policy initiatives. One of these initiatives is the Europe 2020 strategy for growth and jobs with its flagships: a) The Digital Agenda for Europe, 2) the Single Market Act, 3) Industrial policy for globalization era, 4) the Entrepreneurship 2020 Action Plan. Also, the European Fund for Strategic Investments is designed to fill the investment gap created by the economic and financial crisis and to mobilize over $€ 315$ bill to support industrial investments around digital modernization (European Commission, 2016).

The Commission initiated the creation of Digital Entrepreneurship Scoreboard in order to measure national progress in the digital transformation of European industry throughout the 28 EU Member States. The Digital Entrepreneurship Scoreboard provides a comparative assessment of the enabling factors which in the EU 28 Member States create a fertile ground for digital entrepreneurs to thrive and operate successfully, the degree of digitalization of European businesses and the performance of the digital economy across the EU. (European Commission, 2015)

Based on the broad definition of digital entrepreneurship as an activity of putting digital technologies at the heart of business and harnessing their power to generate value and growth, innovate and create jobs, Digital Entrepreneurship Scoreboard follows two dimensions. The first dimension represents the framework conditions for digital entrepreneurship. They capture the environmental factors which favour digital entrepreneurship and cover 5 components: Digital knowledge base and ICT market, Digital business environment, Taxation \& financial environment, Digital skills and eleadership and Entrepreneurial mindset. The output dimension aims at measuring the Digital Entrepreneurship in itself, i.e. the achievements in terms of: digital transformation of businesses, the share of turnover deriving from e-commerce in the EU28, and the business dynamic in the ICT sectors, looking at the birth rate of new ICT startups, their capacity of growing and creating new jobs. (European Commission, 2015)

According to Digital Entrepreneurship Scoreboard 2015 there is a scattered picture across the EU concerning the creation of favorable conditions for digital entrepreneurship. Countries that perform better in terms of enabling factors (UK, France and Germany) are also the ones adopting faster novel technologies and outperform the countries with weaker enabling environments (Spain and Italy), (European Commission, 2015). On the company level there is the group of companies (rather small percentage around 2) which fully leverage digital. They are typically large firms operating in the sector of finance. On the other hand, are still a large number of firms (around 40\%) that do not use any technology associated with digital entrepreneurship (social, mobile, cloud, and big data). These firms are typically SMEs operating in sectors such as mining, construction, manufacturing, transport and storage and utilities. It is estimated that European SMEs - across different sectors - grow two to three times faster when they embrace digital technologies and, more generally, it is recognized that the digital economy will bring new opportunities for growth and jobs. (European Commission, 2015)

In 2017 Commission published The Digital Transformation Scoreboard (DTS) 2017 in order to present further findings about the performance of 
the 28 EU Member States in the digital transformation of their industries and enterprises. There are high disparities between EU Member States as regards digital transformation performance. Sweden is leading the way in terms of digital technology integration and at the bottom of the scale are Bulgaria, Greece, Hungary, and Latvia. (European Commission, 2017)

According to the DTS 2017 survey three out of four European companies regard digital technologies as an opportunity to innovate, grow and thrive to remain competitive in the global marketplace. However, only a few European companies are taking advantage of these opportunities. The adoption rate of new digital technologies is slow. Only $44 \%$ of DTS survey respondents have adopted at least two of the seven digital technologies investigated by the survey. Mobile services, cloud technology and social media are the most widely used digital technologies with 25\%,23\% and 23\% (Figure 3) of survey respondents having integrated these technologies respectively. (European Commission, 2017)

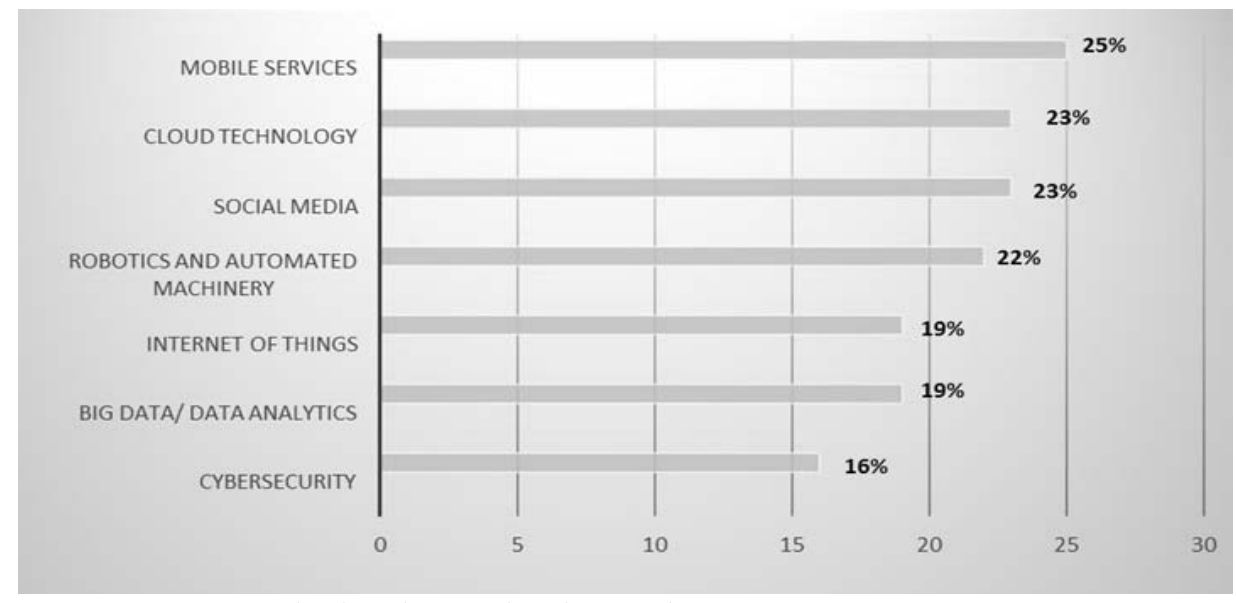

Figure 3: The level of technology adoption in European companies

Source: European Commission, 2017, p. 11

European companies favour "mainstream technologies" from the "first digital wave" over new digital technologies. Lack of skills and costly processes are preventing simultaneous investments in at least two of the seven key digital technologies. Large firms are more likely than SMEs to perform digital transformation and to reap their full benefits.

Concerning the positive results stemming from digital transformation the DTS survey indicates the following findings, (European Commission, 2017):

- $64 \%$ of survey respondents consider that positive outcomes were generated thanks to the integration of digital technologies,

- 54\% of technology adopters have seen their productivity increase or significantly increase,

- 53\% of technology adopters have seen their annual turnover increase or significantly increase,

- Only $6 \%$ of technology adopters have seen their operational costs decrease or significantly decrease.
Member States are called to take action, across all areas of policy (from investments to support knowledge creation, to measures to strengthen skills, access to finance, the entrepreneurship mindset), in order to progress in the creation of favorable environments in which digital entrepreneurs can start and thrive, and make it easier for European businesses to go digital.

\section{DIGITALIZATION PROCESS IN SERBIAN ENTERPRISES}

Serbia is still at the very beginning of digitalization process in its economy and society. Although in the past two decades ICT have generally improved their performance and growth of ICT sector has been reasonable, Serbia still needs to reform its economy in the way that allows ICT to become "the great enabler" it can be (Vidas-Bubanja \& Bubanja, 2016).

Indicators of ICT implementation in Serbian business sector presented in Table 2 proof that domestic enterprises are more or less lagging in 
their efforts and commitment to fully develop and leverage ICTs to boost business transformation and development for reaching higher competitiveness level. According to Serbian state statistical office 99.8\% enterprises in Serbia had the Internet access, and $77 \%$ of enterprises used this Internet access for the creation of web sites in 2016, (SORS, 2016). In the focus of domestic companies is to provide high speed connections with good bandwidth and there were $98.6 \%$ enterprises in 2016 with broadband Internet connection in Serbia. Owing to broadband connections $94.5 \%$ of enterprises were able to use e-government services last year, (SORS, 2016).

Table 2: ICT implementation in Serbian companies and $E U-28$

\begin{tabular}{|c|c|c|}
\hline & EU-28 & SERBIA \\
\hline \multicolumn{3}{|c|}{ Enterprises with Internet access, $\%$} \\
\hline 2014 & 97 & 100 \\
\hline 2015 & 97 & 99,1 \\
\hline 2016 & 97 & 99,8 \\
\hline \multicolumn{3}{|c|}{ Enterprises with WEB sites, \% } \\
\hline 2014 & 74 & 74 \\
\hline 2015 & 75 & 75,2 \\
\hline 2016 & 77 & 80,8 \\
\hline \multicolumn{3}{|c|}{$\begin{array}{l}\text { \% of Enterprises using the Internet for } \\
\text { interaction with public authorities }\end{array}$} \\
\hline 2013 & 87 & 87,6 \\
\hline 2014 & 88 & 92,0 \\
\hline 2016 & 89 & 98,6 \\
\hline \multicolumn{3}{|c|}{$\begin{array}{l}\text { \% Enterprises receiving orders online } \\
\text { (at least } 1 \% \text { ) }\end{array}$} \\
\hline 2014 & 15 & 22,9 \\
\hline 2015 & 17 & 23,3 \\
\hline \multicolumn{3}{|c|}{$\begin{array}{l}\text { \% Enterprises purchasing online } \\
\text { (at least } 1 \% \text { ) }\end{array}$} \\
\hline 2014 & 38 & 40,4 \\
\hline 2015 & 40 & 41,0 \\
\hline \multicolumn{3}{|c|}{ \% Enterprises using ERP } \\
\hline 2014 & 31 & 16,2 \\
\hline 2015 & 36 & - \\
\hline \multicolumn{3}{|c|}{ \% Enterprises using CRM } \\
\hline 2014 & 30 & 14,9 \\
\hline 2015 & 33 & - \\
\hline \multicolumn{3}{|c|}{ \% Enterprises using cloud services } \\
\hline 2014 & 19 & 3,2 \\
\hline 2015 & - & 9,2 \\
\hline 2016 & 21 & 9,3 \\
\hline
\end{tabular}

On the other side, the realization of network transactions still is not on a high level in Serbian business sector. In $201641.0 \%$ of enterprises bought products/services online, and only $23.3 \%$ of enterprises received orders by Internet (Table 2). In the same time, domestic companies are only begging to use advantages of WEB 2.0 services as 28 . $6 \%$ of enterprises use some of social networks for the purpose of their business, (Bubanja, 2015). Also, domestic companies are lagging in value chain management processes as low percentage of companies use ERP and CRM software $(16.2 \%$ and $14.9 \%$ respectively). Cloud services pay only $9.3 \%$ of companies in 2016, (SORS, 2016).

New development environment create challenges for domestic companies to use an opportunity offered by digital economy and to stop with the practice of producing the same products and services in improved ways, but by accepting new business models to divert to the creation of new products and services with the more added value and higher quality levels. Although Serbian companies regard digital as an opportunity, investments in digital technologies remain limited. Frequently, domestic companies are using digital technologies to enhance particular business functions rather than to disrupt or radically transform their businesses. Performed analysis indicate that Serbian companies are still in the "first digital wave", that is they adopted mainstream technologies that correspond to more "basic technologies" (i.e. broadband access and greater bandwidth, IT infrastructure, digital tools for accounting, CRM applications, etc.). For domestic companies the new wave of technology adoption is more challenging and they are very slow in their implementation. (Vidas-Bubanja, 2015)

Whereas many larger companies have started digitalization process in Serbia, SMEs face particular challenges in 'going digital'. The digitalskills gap is hampering the acceleration of digital adoption in Serbia, and a great number of companies still do not consider reskilling strategies to be a priority. Reskilling the workforce across Serbia's industrial sectors is a critical necessity and challenge. A significant percentage of the workforce is at risk of 'functional obsolescence'. SMEs cannot afford long and costly training efforts. Digital reskilling for new and better jobs requires a strong sectoral focus as well as the promotion of cross sector e-skills. A comprehensive strategy is needed to provide an adequate response to the digital leap that industries will experience in the next 5 to 10 years modernization. (European Commission, 2016)

Serbia is also lagging behind its competitors in all types of entrepreneurial activity. The main 
problem in domestic enterprises lies in inadequate use of knowledge, by domestic managers in the first place, as well as the lack of will for constant improvement, (Đorđević et al., 2011). Serbia needs a new wave of entrepreneurs to be the key drivers of the digital transformation of domestic industries and enterprises. Entrepreneurship can be an answer to tackling new business opportunities, boosting market-creating innovations and solving societal challenges, (Vidas-Bubanja \& Bubanja, 2016).

Lack of surveys and data presents an obstacle for deeper insights towards a better understanding of the challenges faced by Serbian industry and enterprises in their transformation journey. As no progress can be realized if it is not measured, Statistical Office of Republic of Serbia should regularly assess and monitor the performance of our industries and enterprises in the digital transformation allowing the tracking of progress on this critically important issue. Digital technology integration index, Digital Transformation Enablers' Index and ICT Start-up Evolution Index created by EU are the samples of good practice in this respect, (European Commission, 2015; 2017). The evidence of this kind will help decision-makers in Serbia to create policies supporting Serbian companies in the digital transformation processes. In the same time, it will enable companies to understand why digital technologies are important and how they can create (or reinforce) their own digital strategy.

\section{CONCLUSION}

Digital technologies have created new markets and unprecedented business opportunities. In Serbia, the key challenge is to ensure that such opportunities are fully captured by industry and service companies, leveraging digitalization to create growth and new jobs.

One of the primary tasks for Serbian government is to accelerate digital transformation, as it presents enormous growth potential for Serbia and the condition for EU membership. Serbia has to provide hard and soft infrastructure in its economy in order to be ready to cope with future demands and requirements from the forth technology revolution and the new ICT wave mainly embodied in mobile communication, social media, cloud, big data analytics, smart devices, connected objects and sensors (Internet of thins).
For reaping the ICT growth benefits Serbia needs to secure a high-quality and affordable infrastructure in all sectors, including high-speed fixed and mobile broadband. Developed infrastructure can be properly used only by talented and educated human capital, that is, by skilled workers and educated managers. Knowledge represents soft infrastructure necessary for the realization of digital economy and information society. Rising awareness and readiness among business and citizens in Serbia for new ICT reality can be a result of wide education policies that encompass different social categories from youth, to those business active and finally to all actively participating in digital economy. In this way new reformed education system based on ICT and innovation is an important way for Serbia to prepare itself for digitally connected world.

In the future, Serbia needs more intensive activities focused on creation of proper environment for further development of digital economy (education, innovation, organizational transformation, etc.). In this respect very importan duties have to be done by business leaders and policymakers. On the one side, business leaders should struggle to implement effective strategies to use the digital world as a source of innovation for their customers or users. At the same time, policymakers need to understand how these new technological applications work in order to better grasp their social, economic and regulatory implications to ultimately set the framework conditions that will allow Serbian companies to take full advantage of digital opportunities. This will enable domestic economy to work more efficient through ICT implementation and realize long-term economic development and overcome recession and transition challenges.

\section{REFERENCES}

Blanchet, M., Rinn, T., Von thaden, G., \& De thieulloy, G. (2014). Think Act Industry 4.0 The new industrial revolution, How Europe will succeed. In A. Dujin, C. Geissler \& D. Horstkötter (Eds.). Munich: Roland Berger Strategy Consultants Gmbh.

Bubanja, I. (2015). Implementation of digital promotion techniques as a prerequisite for increasing the competitiveness of domestic enterprises. Paper presented at the Improving the competitiveness of the Serbian economy as a framework for stimulating investments in Serbia, UKSP-IS 2015, Kosovska Mitrovica, Serbia.

Đorđević, D., Ćoćkalo, D., \& Đurin, S. (2011). Serbian Enterprises and Global Competition Challenges. 
Journal of Engineering Management and Competitiveness (JEMC), 1(1/2), 27-31.

European Commission. (2015). Digital Transformation of European Industry and Enterprises. Brussels: European Commission.

European Commission. (2016). Declaration on the digital transformation of European industry and enterprises. Brussels: European Commission.

European Commission. (2017). Digital Transformation Scoreboard 2017: Evidence of positive outcomes and current opportunities for EU businesses. Brussels: European Commission.

Eurostat. Digital economy and society. Retrieved 15.10.2017, from Eurostat http://ec.europa.eu/eurostat/web/digital-economyand-society/data/database

Gandhi, P., Khanna, S., \& Ramaswamy, S. (2016, April 2016). Which Industries Are the Most Digital (and Why?). Harvard Business Review.

Kerschberg, B. (2017, 1 March 2017). How Digital Disrupts Operations, Business Processes And Customer Experience. Forbes.

Lekić, S., Vidas-Bubanja, M., \& Bogetić, S. (2014). Educated and satisfied worker-foundation of modern and successful company. Journal of Engineering Management and Competitiveness (JEMC), 4(1), 27 33.

Manyika, J., Chui, M., Bughin, J., Dobbs, R., Bisson, P., \& Marrs, A. (2013). Disruptive technologies:
Advances that will transform life, business, and the global economy: McKinsey Global Institute

Marković, G. (2016). Digitalna ekonomija i hrvatsko gospodarstvo. Open info Trend(202), 22-26.

Schumpeter, J. A. (1950). Capitalism, Socialism, and Democracy (3 ed.). New York: Harper and Brothers.

SORS. (2016). The implementation of ICT in the Republic of Serbia (in Serbian). Belgrade: SORS.

Vidas-Bubanja, M. (2015). Digital economy as a new development chance of the Republic of Serbia (in Serbian). In S. Grk (Ed.), The world and Serbiachallenges of development and integration (pp. 89116). Belgrade Institute of social sciences..

Vidas-Bubanja, M., \& Bubanja, I. (2016). The High Quality and Sustainability as Characteristics of doing Business in Digital Connected World (in Serbian). Paper presented at the International Convention on Quality, JUSK-ICQ Belgrade.

Vidas-Bubanja, M., \& Bubanja, I. (2017). Business Competitiveness of Digital Company (in Serbian). Paper presented at the International Convention on Quality, JUSK-ICQ, Belgrade.

Wade, M., \& Tarling, A. (2016). The digital business agility imperative: How companies can fight digital disruption? Lausanne, Switzerland: International Institute for Management Development.

\section{IZAZOVI DIGITALIZACIJE}

Savremeno poslovno okruženje se menja pod uticajem drugog talasa "uznemirujućih" (disruptive) digitalnih tehnologija kao što su mobile aplikacije, društvene mreže, oblak računarstvo, analitika velikih podataka i Internet stvari. Specifičnost ovih digitalnih inovacija koje se definišu kao Četvrta industrijska revolucija je u tome što one izazivaju promene u celim industrijskim sektorima postajući na ovaj način ključni preduslov za dalje konkurentno poslovanje na globalnom nivou. Ovaj rad analizira doprinos novih digitalnih tehnologija ekonomskom rastu nacionalnih ekonomija i ostvarivanju viših nivoa produktivnosti i konkurentnosti preduzeća. $U$ cilju postizanja potrebnog nivoa konkurentnosti savremena preduzeća moraju početi sa procesom digitalne transformacije svog poslovanja što zahteva nove organizacione modele, redizajn poslovnih procesa i nove načine komuniciranja sa partnerskim preduzećima i potrošačima. Prema nekim autorima ovo je jedna od najvećih transformacija poslovnog sveta u zadnjem veku. Potencijali koji mogu biti iskorišćeni u okviru novih digitalnih inovacija su značajni i predstavljaju veliki izazov za sve industrijske grane i nacionalne ekonomije. Analizirana su iskustva EU u razvoju digitalnog preduzetništva, kao i izazovi digitalnih promena za domaća preduzeća.

Kjučne reči: Infromaciono-komunikacione tehnologije, Rast, Produktivnost, Inovacije, Konkurentnost. 